Article

\title{
Repeat Consumer Behavior on Smart P2P Tourism Platforms
}

\author{
Pilar Talón-Ballestero ${ }^{1}$ (D), Fernando E. García-Muiña ${ }^{2}\left(\mathbb{D}\right.$, Juan José Rienda-Gómez ${ }^{3, *(D)}$ \\ and Lydia González-Serrano ${ }^{1}$ \\ 1 Business Economics, Universidad Rey Juan Carlos, 28032 Mostoles, Spain; pilar.talon@urjc.es (P.T.-B.); \\ lydia.gonzalez@urjc.es (L.G.-S.) \\ 2 Business Organization, Universidad Rey Juan Carlos, 28032 Mostoles, Spain; fernando.muina@urjc.es \\ 3 Financial Economics and Accounting and Modern Language, Universidad Rey Juan Carlos, \\ 28032 Mostoles, Spain \\ * Correspondence: juanjose.rienda@urjc.es; Tel.: +34-91488-80-01
}

Received: 11 November 2019; Accepted: 9 December 2019; Published: 11 December 2019

check for updates

\begin{abstract}
Despite the key role played by frequent consumers interacting on smart P2P (peer to peer) tourism platforms, there are hardly any studies on the explanatory variables of their frequency of use. This paper aims to understand the motivational and sociodemographic factors that bring about repeat consumers in collaborative accommodation and transport services. In order to test various assumptions, a set of logistic regressions were made where the dependent variable is the frequency of use and the independent variables are sociodemographic and motivational factors. The results suggest that many consumer attributes recognized as being typical of collaborative platforms, such as young people traveling with friends for leisure who are interested in low prices, have changed. We found that, due to the consolidation of these smart business models, the frequency of use increases with age and for those who travel for work reasons. In addition, it is worth noting the existence of a positive relationship between consumers who provide reviews on these platforms and their frequency of use.
\end{abstract}

Keywords: P2P platforms; smart tourism; business model; sharing economy; collaborative tourism; repeat consumer behavior

\section{Introduction}

Many of the fundamental pillars of the emerging smart tourism are based on simple technology platforms that leverage existing technologies to exploit a different target. These platforms suppose a new business model of smart tourism that represents a change of all or some of the following five elements of the market [1]: object of exchange, actors, structure, institutions, and practices. Therefore, the analysis of the consumers of these services is important in this new context.

Smart peer-to-peer (P2P) platforms are already a reality. It is estimated that, since 2010, Venture Capital funds have invested more than \$23 billion in such platforms [2]. According to Rifkin [3], in 2025, this business model will generate about 335 billion dollars, $50 \%$ of the value of the global sharing economy [4]. Similarly, by 2025, 64\% of adults are expected to use collaborative consumer platforms [4]. In Europe, the collaborative economy generates more than 26 billion euros annually and it shows that "nearly one in four Europeans have already used services offered via collaborative platforms" [5].

These smart business models have been further developed in the tourism sector $[5,6]$, where collaborative tourism companies have surpassed, in a few years, the turnover of traditional tourism companies. This is especially the case with Airbnb and Uber. The former has become the 230th 
company in the "Global 500 Rankings 2019" [7] with the highest brand value, ranking above Marriott International, the world's hotel leader. In addition, it has managed to overtake Booking.com, one of the main online hosting booking platforms [8]. Uber's fleet in New York is now three-fold larger than the number of yellow taxis [2].

This sustained growth contradicts initial perceptions that these were temporary business models, aimed at a young audience, which were hardly going to be able to compete with traditional tourist services. The contextual factors that contributed to the rapid development of this business model, such as the globalization of society caused by the Internet [9-11], the boost from millennials [2,12,13], and the global economic crisis that favored the reuse of resources [14] are less influential now. Therefore, no one doubts that collaborative tourism is here to stay and will continue to grow $[5,15]$.

The consolidation of these smart tourism business models has been supported by the highest degree of satisfaction and recommendation of these services versus the traditional ones $[16,17]$. Both domestic [18] and European studies [5] show the greatest tendency for users to recommend collaborative platforms.

Smart P2P tourism platforms are adapting their products to better fit the needs of consumers than traditional services, which creates the perception of quality and thus increases its frequency of use [12,19-22]. This increased frequency of use causes greater confidence in the product and service [23-25], which is particularly relevant, since consumer insecurity and mistrust have been established as some of the most important reasons for the non-use of collaborative platforms [22,26,27]. In addition, the frequency of use is usually related to the service recommendation (e-wom) [28-31].

Despite the success of these smart models, there are few studies focused on P2P accommodation user profiles and their behavior. Understanding the impact of such models on the tourism and hospitality industry is still in its early stage in the European Union [32]. Although there are works on motivational factors for the use of the collaborative economy [21,22,33-35], research on the variables that affect consumer repetition is scarce [36,37]. In addition, the evolution of the contextual factors that contributed to the development of these models motivates the need for new empirical evidence on the factors that are consolidating them. Therefore, the objective of this work is to determine the motivational and sociodemographic variables that influence the frequency of use of the services of smart P2P tourism platforms. The analysis is particularized for the two most relevant sectors in collaborative tourism: accommodation and transport. In order to detect whether there have been changes over time, the factors related to the non-use of smart P2P tourism platforms will also be examined.

The rest of the article is organized as follows: after this introduction, the theoretical basis that supports the working hypotheses is developed. Subsequently, the methodology, results, and discussion of the empirical study are presented. Finally, the main conclusions of the work, as well as the limitations and future lines of research, are described.

\section{Theory and Hypotheses}

The rapid expansion and consolidation of smart P2P tourism platforms has led, as mentioned above, to extensive literature on the motivational factors that influence the adoption of these services. The same cannot be said about the profile of the collaborative tourist because research on this topic is almost non-existent. The reason for this, as some authors have pointed out, may be the differences in profiles, depending on the country concerned [26,37].

Beyond the profile or motivations for the use of collaborative tourism, one of the factors that has contributed to the success of these platforms has been the high frequency of use [12,38,39], as it is key in consolidating trust and security in these services [23-25]. Given the lack of regulation in collaborative tourism, high levels of recommendation and e-wom have helped to eliminate uncertainty and bring these platforms closer to consumers. According to the Eurobarometer [5], recommendations and rankings are one of the most appreciated aspects by users of P2P platforms.

However, as mentioned above, there is little evidence of the determinants of consumer repetition in collaborative tourism, as well as the demographic variables that influence their use. Thus, some authors 
relate these to age [40] and gender [41]. The latter states that women are more reluctant to use them due to a fear of being scammed. Other studies conclude that the age of users is mostly between 25 and 34 years, so they are typically millennials who are more likely to be single and childless $[5,27,34,35,42-44]$.

Nevertheless, it is possible to find a broad research framework on the profile of the repeat consumer in traditional tourist services, most of whom focus on touristic destinations [45-53]. There is less research on other sectors, such as hotels [54-56]. All these studies show the major influence of sociodemographic variables (such as education, gender, age, etc.). Regarding the frequency of use of hotel accommodations, Talón-Ballestero et al. [55] show that gender, age, and family conditions are relevant. In this work, repeat consumers match with a younger segment, those without children and single men.

Considering both traditional and collaborative tourist services, the first hypothesis is presented as follows:

Hypothesis (H1). The frequency of use of smart P2P platforms in tourism is higher for single, young, childless men. This hypothesis can be divided into the following three sub-hypotheses:

Hypothesis $\left(\mathbf{H 1}_{\mathbf{A}}\right)$. The frequency of use of smart P2P platforms in tourism is higher for single men.

Hypothesis (H1 $\mathbf{B})$. The frequency of use of smart P2P platforms in tourism is higher for young men.

Hypothesis $\left(\mathbf{H 1}_{\mathrm{C}}\right)$. The frequency of use of smart P2P platforms in tourism is higher for childless men.

Homburg and Giering [57] and Skogland and Siguaw [58] establish the influence of the contextual variables of travel (including the purpose of travel) on frequency of use and loyalty. In the case of collaborative tourism, the main reason for use is leisure and enjoyment $[34,35,40]$ and the way to travel would be as a couple and with friends [34,59]. Taking all this into account, hypothesis 2 is set out as follows:

Hypothesis (H2). The frequency of use of smart P2P platforms in tourism is higher for leisure travelers, traveling couples, or travelers accompanied by friends. This hypothesis can be divided into the following three sub-hypotheses:

Hypothesis $\left(\mathrm{H}_{2}\right)$. The frequency of use of smart P2P platforms in tourism is higher for leisure travelers.

Hypothesis (H2B $)$. The frequency of use of smart P2P platforms in tourism is higher for traveling couples.

Hypothesis $\left(\mathbf{H 2}_{\mathrm{C}}\right)$. The frequency of use of smart P2P platforms in tourism is higher for travelers accompanied by friends.

In collaborative tourism, cost savings or economic benefits are considered to be the main factors of choice by tourists $[5,21,26,34,36,60,61]$. In any case, some current studies such as Kim [62] state that money savings are not significantly related to consumers' decision-making processes.

On the other hand, according to Kim, Kim, and Kim [63] as well as Morosan and Jeong [64], the perceived ease of use has a significant impact on the use of platforms. In this sense, Cusumano [65] points out that the success of some smart P2P tourism platforms, such as Airbnb, comes from their ease of use, and the conclusions of the Eurobarometer [5] indicate that the most frequently mentioned advantage of collaborative platforms is convenient access to services.

Finally, some authors establish the major importance of social interaction with the environment for the choice of collaborative tourism $[12,26]$. Therefore, this interaction becomes one more attribute of the tourist service that is capable of producing satisfaction and loyalty in the consumer. 
Even though these platforms foster a sustainable market, it is not a very relevant factor when choosing collaborative accommodation. The evidence indicates that users attend to more basic needs and that the suppliers have a more community-oriented behavior [21,33]. However, this is different to in the transport sector, since according to Böcker and Meelen [66] sustainability could be a motivation for sharing trips and cars.

Considering all these authors, hypothesis 3 can be set as follows:

Hypothesis (H3). The frequency of use of smart P2P platforms in tourism is higher in people who value price, ease of use, and social interaction. In addition, environmental or sustainable motivations largely affect consumer behavior on smart transport platforms. This hypothesis can be divided into the following four sub-hypotheses:

Hypothesis $\left(\mathrm{H}_{\mathbf{A}}\right)$. The frequency of use of smart P2P platforms in tourism is higher in people who value the price.

Hypothesis ( $\left.\mathbf{H}_{\mathbf{B}}\right)$. The frequency of use of smart P2P platforms in tourism is higher in people who value ease of use.

Hypothesis (H3C). The frequency of use of smart P2P platforms in tourism is higher in people who value social interaction.

Hypothesis (H3 $\left.\mathbf{3}_{\mathbf{D}}\right)$. The frequency of use of smart P2P transport platforms in tourism is higher in people who value environmental protection and sustainability.

E-wom has a positive effect on buyback intent and decreases mistrust [67-69]. This is especially valuable in a context where so far there has been major uncertainty when it comes to making transactions. In addition, people who are more active on social networks and who own smartphones tend to have a higher frequency of use on collaborative tourism platforms [37], so they become key revitalizers of such platforms. However, no study has found a significant relationship between reviewers (who rate the service positively or negatively) and their frequency of use of these platforms. The following hypothesis is raised with an exploratory nature:

Hypothesis (H4). The frequency of use of smart P2P platforms in tourism is higher for people who review the services on these platforms.

Although the purpose of this research is to determine the factors that affect the frequency of use of the platforms, it has also been of interest in the literature to establish the reasons for non-use of the sharing economy. In this sense, trust has been a key factor affecting consumer behavior on online platforms [70]. The lack of security and regulation has been an obstacle that has negatively affected the attitude of consumers, thus becoming a barrier to the use of these platforms [26,27,37]. According to Huang, Liu, Lai, and Li [71], the significant difference of perceived risks and behavioral intentions between users and non-users means that experiencing P2P accommodation can significantly reduce tourists' risk perception and increase their purchase intentions. However, it seems appropriate to point out that the heavy use and maturity achieved by these business models over time may have changed the reasons for not using them. Therefore, this work also analyzes, in an exploratory way, the reasons for non-use of smart P2P tourism platforms.

\section{Methodology}

The population under study consists of all individuals ranging between the ages of 18-65, living in Spain, who have a profile on a social network and/or instant messaging service: Facebook, Instagram, Youtube, Twitter, and WhatsApp, the best known and the most followed platforms according to the iab.spain's 2019 Annual Social Network Study. In addition, people who are more active on social 
networks and who own smartphones tend to have a higher frequency of use on collaborative tourism platforms [37].

The survey was conducted from April 22 to May 23, 2018. A non-experimental, exploratory, correlational, and cross-sectional design was carried out by means of a horizontal networking, a form of social networking that usually starts with a multiple (though relatively small) number of initial contacts and then uses these to establish links with other research participants [72], via the Internet, social media, and "WhatsApp". Horizontal networking uses both strong and weak ties to bridge into new social networks, casting the sampling and recruitment net wide rather than deep. Following this procedure, we obtained a larger sample, around 500 individuals, and which, after the filtering and debugging of the information according to its relevance, was eventually composed of 331 individuals. Despite not having used probabilistic sampling, the sample size allows us to obtain representativeness and control bias.

In order to test the assumptions, a set of logistic regressions were made. The Statistical Software package used was SPSS 22.0. The dependent variable (frequency of use) behaves in a dichotomous manner-where category 1 is defined as those cases where the collaborative platforms have been used on less than five occasions and category 2 corresponds to those respondents who have used such platforms on five or more occasions. Alemi [37] uses a similar classification to contrast the frequency of use.

The independent variables (similar to those used by Alemi [37] are age $(18-25 ; 26-35 ; 36-45 ; 46-65$ years), marital status (single, married, coupled), children (yes/no), accompaniment (yes/no), reason (business/leisure), reasons for use (dichotomous items in different variables) and if they review or not (yes/no). This issue is discussed in two subsamples related to the sharing sector (accommodation and transport).

Table 1 shows the main characteristics of the sample.

Table 1. Socio-demographic characteristics of the sample.

\begin{tabular}{|c|c|c|c|c|c|c|c|c|c|c|c|}
\hline \multirow[b]{2}{*}{$\mathrm{N}=331$} & \multicolumn{2}{|c|}{ Gender } & \multicolumn{4}{|c|}{ Age } & \multicolumn{3}{|c|}{ Marital Status } & \multicolumn{2}{|c|}{ Children } \\
\hline & Female & Male & $18-25$ & $26-35$ & $36-45$ & $46-65$ & Married & Cohabiting & Single & Yes & No \\
\hline Frequency & 207 & 124 & 101 & 77 & 54 & 99 & 115 & 108 & 108 & 205 & 126 \\
\hline$\%$ & 62.5 & 37.5 & 30.5 & 23.3 & 16.3 & 29.9 & 34.7 & 32.6 & 32.6 & 61.9 & 38.1 \\
\hline
\end{tabular}

\section{Main Findings}

As mentioned in the theoretical basis, this work delves into the factors that determine the frequency of use of smart P2P tourism platforms. We have also considered the descriptive analysis of the reasons why these platforms are not used (164 of the respondents). It is possible to emphasize that ignorance and a lack of trust or regulation have lost importance as inhibitors to the use of the sharing economy. Our results show that $92.7 \%$ of those who do not use the sharing economy have heard of it, while $22.6 \%$ allude their non-use to lack of trust and $3.7 \%$ to lack of regulation. From the point of view of the reasons for non-use, "no need" (56.7\%) was highlighted.

With respect to factors affecting the frequency of use as shown in Table 2, the model explains $69.5 \%$ of the frequency of use of collaborative platforms in the case of accommodation. Similarly, it can be observed that, for transport, this value is $63.5 \%$. Therefore, the explanatory capacity of the model is high. In addition, as shown in Table 3, the model adequately classifies sample observations in the two categories of platforms used ( $86 \%$ for accommodation and $81.1 \%$ for transport). 
Table 2. Summary of the Accommodation and Transport Model.

\begin{tabular}{cccc}
\hline Model & Log of Likelihood & Cox and Snell R Sq & Nagelkerke R Sq \\
\hline Accommodation & 67.774 & 0.517 & 0.695 \\
Transport & 93.890 & 0.476 & 0.635 \\
\hline
\end{tabular}

Table 3. Sample observations classification.

\begin{tabular}{|c|c|c|c|c|c|}
\hline & \multirow{3}{*}{\multicolumn{2}{|c|}{ Observed }} & \multicolumn{3}{|c|}{ Forecasted } \\
\hline & & & \multicolumn{2}{|c|}{ RECODING FREQUENCY OF USE } & \multirow{2}{*}{ Percentage of Fi } \\
\hline & & & Fewer than 5 & 5 or More & \\
\hline \multirow{3}{*}{ Accommodation } & RECODING & Fewer than 5 & 51 & 13 & 79.7 \\
\hline & FREQUENCY OF USE & 5 or more & 11 & 52 & 82.5 \\
\hline & \multicolumn{2}{|c|}{ Global percentage } & & & 81.1 \\
\hline \multirow{3}{*}{ Transport } & RECODING & Fewer than 5 & 53 & 9 & 85.5 \\
\hline & FREQUENCY OF USE & 5 or more & 6 & 39 & 86.7 \\
\hline & \multicolumn{2}{|c|}{ Global percentage } & & & 86.0 \\
\hline
\end{tabular}

In the case of accommodation (see Table 4), $\mathrm{H} 1$ is partially rejected since, although married people or living with a partner demonstrate a lower frequency of use, confirming $\mathrm{H}_{\mathrm{A}}$, this frequency also increases with age, contrary to our expectations $\left(\mathrm{H}_{\mathrm{B}}\right)$. Moreover, having children or being male or female is not significant $\left(\mathrm{H} 1_{\mathrm{C}}\right)$. This result differs partially from what Alemi [37] points out, as in our results, sociodemographic variables do not explain the frequency of use since, in this case, only marital status and age are indeed significant.

Table 4. Logistic regression results: accommodation.

\begin{tabular}{cccccc}
\hline Variables & B & Wald & df & Sig. & Exp(B) \\
\hline GENDER(1) & -0.162 & 0.051 & 1 & 0.821 & 0.850 \\
AGE_C & & 3.544 & 3 & 0.315 & \\
AGE_C(1) & 0.649 & 0.639 & 1 & 0.424 & 1.913 \\
AGE_C(2) & 0.592 & 0.170 & 1 & 0.680 & 1.807 \\
AGE_C(3) & 4.137 & 3.236 & 1 & 0.072 & 62.593 \\
MARITAL_STATUS Single & & 4.961 & 2 & 0.084 & \\
MARITAL_STATUS (1) & -1.081 & 0.863 & 1 & 0.353 & 0.339 \\
MARITAL_STATUS (2) & -4.313 & 4.834 & 1 & 0.028 & 0.013 \\
CHILDREN(1) & 1.958 & 1.080 & 1 & 0.299 & 7.083 \\
MOT_FORWORK(1) & 2.098 & 3.702 & 1 & 0.054 & 8.150 \\
MOT_LEISURE(1) & -0.561 & 0.574 & 1 & 0.448 & 0.571 \\
MOT_OTHER(1) & -19.122 & 0.000 & 1 & 1.000 & 0.000 \\
COMP_ALONE(1) & 0.388 & 0.209 & 1 & 0.648 & 1.473 \\
COMP_FRIEDS(1) & 4.272 & 9.205 & 1 & 0.002 & 71.677 \\
COMP_PARTNER(1) & 2.601 & 4.959 & 1 & 0.026 & 13.481 \\
COMP_FAMILY(1) & -0.467 & 0.286 & 1 & 0.593 & 0.627 \\
COMP_WORK(1) & 4.977 & 6.581 & 1 & 0.010 & 145.095 \\
MOTUSE_CHEAP(1) & 0.849 & 0.313 & 1 & 0.576 & 2.338 \\
MOTUSE_EASE(1) & 1.076 & 1.625 & 1 & 0.202 & 2.933 \\
MOTUSE_PERSONAL(1) & -1.467 & 1.812 & 1 & 0.178 & 0.231 \\
MOTUSE_SUSTAINAB(1) & 1.002 & 0.845 & 1 & 0.358 & 2.723 \\
MOTUSE_CONTACT(1) & 0.385 & 0.138 & 1 & 0.710 & 1.469 \\
VAL_ONLINE(1) & 4.230 & 12.347 & 1 & 0.000 & 68.684 \\
INTERCEPT & -30.808 & 0.000 & 1 & 0.998 & 0.000 \\
\hline & & & & & \\
\hline
\end{tabular}

As for $\mathrm{H} 2$, the increase in frequency of use is confirmed in the case of people accompanied by friends or partners (confirming $\mathrm{H} 2_{\mathrm{B}}$ and $\mathrm{H} 2_{\mathrm{C}}$ ), but also, in the case of those who travel for work purposes with co-workers (not confirming $\mathrm{H}_{2} \mathrm{~A}$ ). Therefore, this hypothesis is not confirmed in all its 
terms either. This seems to ratify that the sharing economy $[73,74]$ is being strongly incorporated into the professional/work segment, especially among older people.

Regarding the reasons set out in $\mathrm{H} 3$, none of them are significant, contrary to what was expected.

Finally, H4 is confirmed, as people who review online services have a very high frequency of use.

In the case of transport (see Table 5), H1 is also not confirmed in its entirety although, in this case, the frequency of use decreases with age as expected (confirming $\mathrm{H} 1_{\mathrm{B}}$ ) [37]. However, marital status, gender, or children are not significant $\left(\mathrm{H}_{\mathrm{A}}\right.$ and $\left.\mathrm{H} 1_{\mathrm{C}}\right)$.

Table 5. Logistic regression results: transport.

\begin{tabular}{cccccc}
\hline Variables & B & Wald & df & Sig. & Exp(B) \\
\hline GENDER(1) & 0.181 & 0.096 & 1 & 0.757 & 1.199 \\
AGE_C & & 11.877 & 3 & 0.008 & \\
AGE_C(1) & 0.301 & 0.210 & 1 & 0.647 & 1.351 \\
AGE_C(2) & -6.934 & 10.745 & 1 & 0.001 & 0.001 \\
AGE_C(3) & -2.730 & 3.763 & 1 & 0.052 & 0.065 \\
MARITAL-STATUS & & 0.858 & 2 & 0.651 & \\
MARITAL_ST(1) & -0.549 & 0.552 & 1 & 0.458 & 0.577 \\
MARITAL_ST(2) & 0.206 & 0.029 & 1 & 0.865 & 1.228 \\
CHILDREN(1) & 1.322 & 0.938 & 1 & 0.333 & 3.751 \\
MOT_FORWORK(1) & 1.722 & 3.509 & 1 & 0.061 & 5.597 \\
MOTLEISURE(1) & 0.754 & 1.258 & 1 & 0.262 & 2.126 \\
COMP_ALONE(1) & 2.100 & 8.821 & 1 & 0.003 & 8.169 \\
COMP_FRIENDS(1) & -0.201 & 0.043 & 1 & 0.835 & 0.818 \\
COMP_PARTNER(1) & 0.982 & 1.957 & 1 & 0.162 & 2.669 \\
COMP_FAMILY(1) & 0.554 & 0.553 & 1 & 0.457 & 1.740 \\
COMP_WORK(1) & 3.899 & 9.057 & 1 & 0.003 & 49.371 \\
MOTUSE_CHEAP(1) & -1.232 & 1.920 & 1 & 0.166 & 0.292 \\
MOTUSE_EASE(1) & -0.199 & 0.092 & 1 & 0.762 & 0.820 \\
MOTUSE_PERSONAL(1) & -0.380 & 0.221 & 1 & 0.639 & 0.684 \\
MOTUSE_SUSTAINAB(1) & -1.369 & 3.466 & 1 & 0.063 & 0.254 \\
MOTUSE_CONTACT(1) & 2.359 & 3.545 & 1 & 0.060 & 10.577 \\
VAL_ONLINE(1) & 3.215 & 15.214 & 1 & 0.000 & 24.903 \\
INTERCEPT & -3.229 & 5.113 & 1 & 0.024 & 0.040 \\
\hline
\end{tabular}

$\mathrm{H} 2$ is rejected as the frequency of use increases for individuals (not confirming $\mathrm{H} 2_{B}$ and $\mathrm{H}_{C}$ ) and co-workers (not confirming $\mathrm{H}_{\mathrm{A}} \mathrm{A}$ ). In addition, the professional motif is highly representative of a high frequency of use, as in the Alemi study [37]. This circumstance confirms the above-mentioned point on the important incorporation of the collaborative economy in the workplace.

As for $\mathrm{H} 3$, contact with the cultural and local socio-environment is significant and increases the frequency of use (confirming $\mathrm{H} 3_{\mathrm{C}}$ ) and sustainability as a motivation to increase frequency is also significant just for transport (confirming $\mathrm{H}_{3}$ ); however, neither the price nor the ease of use are significant (not confirming $\mathrm{H}_{3}$ and $\mathrm{H}_{3}$ ).

Once again, e-wom remains significant, although to a lesser extent than in the case of accommodation, while not rejecting the $\mathrm{H} 4$.

\section{Discussion}

In this study, logistic regressions were conducted to understand the motivational and sociodemographic factors that bring about repeat consumers in collaborative accommodation and transport services. The dependent variable is frequency of use and the independent are sociodemographic and motivational variables. The empirical analysis of 341 individuals ranged between the ages of 18-65, living in Spain, who have a profile on a social network and/or instant messaging service (Facebook, Instagram, Youtube, Twitter, and WhatsApp), obtained the following results: 
First, our research points out that the differences found between the two types of tourism businesses (traditional and collaborative) and, within the collaborative economy, between the two activities that have achieved greater development (accommodation and transport) offer reasons for reflection and discussion.

Second, age as a differentiating element between users of accommodation and transport business models, seems to be losing relevance and the orientation of the platforms towards young users is not confirmed, especially in the case of accommodation. This evidence contradicts other studies concluding that the age of users is mostly between 25 and 34 years, so they are typically millennials [5,27,34,35,42-44]. Similarly, gender does not appear as a discriminant variable, since women have already overcome their initial hesitancy towards the use of platforms, contrary to Monaco [41] who states that women are more reluctant to use them due to a fear of being scammed.

Third, another fact also emerges that marks a change of trend. In both cases, an increase in the frequency of use of those who travel for professional purposes is detected, either individually or with co-workers, as is the case in Alemi's study [37]. However, these results would go against other previous studies that indicate that the main reason for using these platforms is leisure and enjoyment $[34,35,40]$ and the way to travel would be as a couple and with friends $[34,59]$. Nonetheless, from our point of view, the reason for this trend change is the consolidation of these platforms extending their use to all sectors of the population.

Fourth, price, ease of use, socio-environment contact and sustainability traditionally considered as drivers in the use of these platforms in much research $[5,21,26,34,36,60,61,63-65]$, are losing strength in both sectors. This would support Kim's [62] results regarding price. However, in collaborative transport, local and socio-environment contact and sustainability are still strong motivations. It should be noted that, despite the fact that these platforms promote a sustainable market, it is not a very relevant factor when choosing collaborative accommodation. Although it is part of the consumer's attitude, it does not necessarily translate into their behavioral intentions, that is, it is not directly associated with participation, unless it is found along with other more relevant factors. The evidence indicates that users attend to more basic needs and it is the suppliers that have a more community-oriented behavior [21,33]. In addition, Pesonen and Tussyadiah [40], observed that, even for those people who were mostly attracted to social and environmental aspects, sustainability was their fourth motivation. Therefore, as Böcker and Meelen [66] suggested, sustainability is motivating when it comes to collaborative transport, but it is not a determining factor in accommodation.

Fifth, another interesting issue is the relationship between reviewers and frequency of use. Thus, people who review online services develop a very high frequency of use both in the accommodation and transport sectors. This result is very relevant, since it is the first time that the relationship between reviewers and repeat consumers is demonstrated.

Finally, the consolidation of smart P2P tourism platforms seems to be supported by the fact that the lack of security and regulation, traditional barriers to their use [22,26,27], have ceased to be relevant. Frequent use and extensive commentary among members of the collaborative community have made these business models more transparent. Non-need has become the fundamental reason identified in this study for non-use.

\section{Conclusions}

This paper was motivated by the gap detected in the literature regarding the variables that influence the frequency of use of smart P2P tourism platforms. When this phenomenon has been addressed, studies have focused on determining the motivations for its adoption or impediments to its use. Nonetheless, in the case of traditional tourism, determining the profile of the repeat consumer and the reasons for such repetition have been of increasing interest.

Contrary to those who considered the sharing economy a transient phenomenon in tourism, it has been consolidated over time. Socio-economic and technological factors explain the emergence of smart P2P platforms. Nevertheless, these alternative business models have traditionally suffered from higher 
levels of uncertainty and lack of regulation. For that reason, trust and reputation are considered key success factors for these companies that can be developed by loyal customers who use the platform regularly and share their experiences through social media.

The study, therefore, provides a clear and relevant perspective on the changes taking place in the context of the sharing economy in tourism, in order to guide decision-making in companies within the industry. From a marketing point of view, a clear understanding of the factors affecting the increased use by consumers on smart P2P tourism platforms will facilitate the development of effective strategies leading to positive behavior, thus increasing the loyalty of their consumers and the importance of this sustainable tourism model. Similarly, this issue is relevant to traditional tourism companies that are threatened by these new business models in all their strategic segments [75].

Our results show that there are significant changes to initial paradigms on the use of smart P2P tourism platforms regarding the repeat consumer. With respect to the motivational variables, neither the price nor the ease of use are significant in repeat consumers' behavior anymore. Therefore, the strategies that derive from these results for such platforms focus on the product rather than on the price or the distribution channel.

Other relevant managerial implications that can be drawn are the reorientation of the targeting between traditional and P2P tourism businesses. This is the case of several traditional international hotel chains, like Accor or Marriot, that are entering home-sharing business targets. The recent powerful incorporation of the collaborative tourism business model is a clear threat to conventional businesses and, at the same time, an important opportunity for the collaborative accommodation and transportation sectors. In many cases, the separation between the traditional tourism segments and those based on the sharing economy has disappeared.

On one hand, the smart P2P platforms should consider older people and business travelers as an important new target as they tend to be higher frequency repeat users. Therefore, it would be advisable for these platforms to direct specific actions aimed at these targets to strengthen their loyalty. On the other hand, hotels should increase their marketing actions and review the approach of their products aimed at these segments. In the specific case of transportation, the P2P platforms are considered to be a source of sustainability that can hardly be replicated by traditional businesses, which favors the repetition of their use.

In short, the repeat consumer has become an intangible resource of major value to tourism businesses based on the sharing economy principles, since it is an efficient strategic tool to counteract any lack of confidence. Coherently, given the importance of the reviewer consumers, it is recommended that platforms address these consumers using direct marketing strategies and try to strengthen their loyalty.

This work presents several limitations that will guide the development of future research. The results are limited to Spanish users of more common social media. Therefore, the evidence shown in this paper cannot be generalized to different social or geographical contexts. Moreover, there is a need to develop a broader study that compares traditional and collaborative services and analyzes consumer behavior, motivational factors of adoption, frequency of use, and satisfaction.

Given the results of this work, two lines of research in smart P2P tourism platform are raised for the future: (a) to deepen the study of the business segment, considering accommodation and transportation, since there are some notable differences between this and other segments when explaining repeat consumer behavior, and (b) to extend the research on reviewing consumers and their loyalty.

Author Contributions: Conceptualization: P.T.-B. and L.G.-S.; Methodology: F.E.G.-M. and J.J.R.-G.; Software: F.E.G.-M. and J.J.R.-G.; Formal analysis: P.T.-B., L.G.-S., F.E.G.-M. and J.J.R.-G.; Investigation: P.T.-B.; Data curation: F.E.G.-M., J.J.R.-G. and L.G.-S.; Writing: P.T.-B., F.E.G.-M., J.J.R.-G. and L.G.-S.

Funding: This research received no external funding.

Conflicts of Interest: The authors declare no conflicts of interest. 


\section{References}

1. Sigala, M. From demand elasticity to market plasticity: A market approach for developing revenue management strategies in tourism. J. Travel Tour. Mark. 2015, 32, 812-834. [CrossRef]

2. Wallenstein, J.; Shelat, U. Hopping Aboard the Sharing Economy. Boston Consulting Group. Available online: http://image-src.bcg.com/Images/BCG-Hopping-Aboard-the-Sharing-Economy-Aug-2017_ tcm104-168558.pdf (accessed on 10 July 2019).

3. Rifkin, J. La Sociedad de Coste Marginal Cero: El Internet de Las Cosas, el Procomún Colaborativo y el Eclipse Del Capitalismo; Paidós Barcelona: Barcelona, Spain, 2014.

4. PwC. The Sharing Economy: Consumer Intelligence Series; PricewaterhouseCoopers: New York, NY, USA, 2015.

5. European Commission. Flash Eurobarometer Survey 467 Report: The Use of the Collaborative Economy. 2018. Available online: https://www.google.com/search?client=firefox-b-dq=Flash+Eurobarometer+Survey+ 467+ReportThe+use+of+the+collaborative+economy (accessed on 26 August 2019).

6. Richard, B.; Cleveland, S. The future of hotel chains: Branded market places driven by the sharing economy. J. Vacat. Mark. 2016, 22, 239-248. [CrossRef]

7. Brand Finance. Global 500 Ranking 2019. Available online: https://brandirectory.com/rankings/global-5002019 (accessed on 15 August 2019).

8. SimilarWeb. Top Websites Ranking. Available online: https:/www.similarweb.com/corp/resources/ (accessed on 19 February 2018).

9. Botsman, R.; Rogers, R. Beyond Zipcar: Collaborative consumption. Harv. Bus. Rev. 2010, 88, 30.

10. Belk, R. You are what you can access: Sharing and collaborative consumption online. J. Bus. Res. 2014, 67, 1595-1600. [CrossRef]

11. Sigala, M. Collaborative commerce in tourism: Implications for research and industry. Curr. Issues Tour. 2017, 20, 346-355. [CrossRef]

12. Guttentag, D. Airbnb: Disruptive innovation and the rise of an informal tourism accommodation sector. Curr. Issues Tour. 2015, 18, 1192-1217. [CrossRef]

13. Amaro, S.; Andreu, L.; Huang, S. Millenials' intentions to book on Airbnb. Curr. Issues Tour. 2019, 22, 2284-2298. [CrossRef]

14. Moreno-Izquierdo, L.; Ramón-Rodríguez, A.; Such Devesa, M.J. Turismo colaborativo: ¿Está Airbnb transformando el sector del alojamiento? Economistas 2016, 150, 107-119.

15. Alonso-Almeida, M.D.M.; Cádiz-Gómez, M.C.; Flecha-Barrio, M.D.; González-Serrano, L.; Rodríguez-Antón, J.M.; Talón-Ballestero, P.T. La denominada economía colaborativa, ¿de verdad lo es? AECA Rev. 2018, 121, 15-18.

16. Armas, R.J.D.; Taño, D.G.; Rodríguez, F.J.G. Airbnb como nuevo modelo de negocio disruptivo en la empresa turística: Un análisis de su potencial competitivo a partir de las opiniones de los usuarios. In Proceedings of the XVIII Congreso AECIT, Benidorm, Spain, 26-28 November 2014.

17. Georgios, Z.; Davide, P.; John, B. A First Look at Online Reputation on Airbnb, Where Every Stay is Above Average. Available online: http://dx.doi.org/10.2139/ssrn.2554500 (accessed on 28 January 2015).

18. HomeAway. VI Barómetro del Alquiler Vacacional. Universidad de Salamanca. Available online: https://www.homeaway.es/info/homeaway-lab/estudios/barometro-alquiler-vacacional/estudionacional-multimedia/estudio (accessed on 20 August 2019).

19. Sheth, J.N.; Sethia, N.K.; Srinivas, S. Mindful consumption: A customer-centric approach to sustainability. J. Acad. Mark. Sci. 2011, 39, 21-39. [CrossRef]

20. Owyang, J.; Tran, C.; Silva, C. The Collaborative Economy; Altimeter: San Mateo, CA, USA, 2013.

21. Hamari, J.; Sjöklint, M.; Ukkonen, A. The sharing economy: Why people participate in collaborative consumption. J. Assoc. Inf. Sci. Technol. 2015, 67, 2047-2059. [CrossRef]

22. Tussyadiah, I.P. An Exploratory Study on Drivers and Deterrents of Collaborative Consumption in Travel. In Information and Communication Technologies in Tourism; Tussyadiah, I., Inversini, A., Eds.; Springer: Cham, Switzerland, 2015. [CrossRef]

23. Shapiro, D.; Sheppard, B.H.; Cheraskin, L. Business on a handshake. Negotiat. J. 1992, 8, 365-377. [CrossRef]

24. Lewicki, R.J.; Bunker, B.B. Trust in relationships: A model of development and decline. In Conflict, Cooperation and Justice; Bunker, B.B., Rubin, J.Z., Eds.; Jossey-Bass: San Francisco, CA, USA, 1995.

25. McCo, P. Transaction frequency and trust in internet buying behaviour. Irish Mark. Rev. 2002, 15, 35. 
26. Tussyadiah, I.P.; Pesonen, J. Impacts of peer-to-peer accommodation use on travel patterns. J. Travel Res. 2016, 55, 1022-1040. [CrossRef]

27. So, K.K.F.; Oh, H.; Min, S. Motivations and constraints of Airbnb consumers: Findings from a mixed-methods approach. Tour. Manag. 2018, 67, 224-236. [CrossRef]

28. Park, C.; Lee, T.M. Information direction, website reputation and e-wom effect: A moderating role of product type. J. Bus. Res. 2009, 62, 61-67. [CrossRef]

29. Cantallops, A.S.; Salvi, F. New consumer behaviour: A review of research on e-wom and hotels. Int. J. Hosp. Manag. 2014, 36, 41-51. [CrossRef]

30. Confente, I. Twenty-five years of word-of-mouth studies: A critical review of tourism research. Int. J. Tour. Res. 2014, 17, 613-624. [CrossRef]

31. Yen, C.L.A.; Tang, C.H.H. Hotel attribute performance, e-wom motivations, and media choice. Int. J. Hosp. Manag. 2015, 46, 79-88. [CrossRef]

32. Juul, M. The Sharing Economy and Tourism: Tourist Accommodation; European Parliamentary Research Service: Strasbourg, France, 2015; pp. 1-6. Available online: http://www.europarl.europa.eu/RegData/etudes/BRIE/ 2015/568345/EPRS_BRI(2015)568345_EN.pdf (accessed on 20 January 2019).

33. Bellotti, V.; Ambard, A.; Turner, D.; Gossmann, C.; Demkova, K.; Carroll, J.M. A Muddle of Models of Motivation for Using Peer-to-Peer Economy Systems. In Proceedings of the 33rd Annual ACM Conference on Human Factors in Computing Systems (CHI '15), Seoul, Korea, 18-23 April 2015; ACM: New York, NY, USA; pp. 1085-1094. [CrossRef]

34. Guttentag, D.; Smith, S.; Potwarka, L.; Havitz, M. Why tourists choose Airbnb: A motivation-based segmentation study. J. Travel Res. 2018, 57, 342-359. [CrossRef]

35. Tussyadiah, I.P.; Pesonen, J. Drivers and barriers of peer-to-peer accommodation stay-An exploratory study with American and Finnish travellers. Curr. Issues Tour. 2018, 21, 703-720. [CrossRef]

36. Möhlmann, M. Collaborative consumption: Determinants of satisfaction and the likelihood of using a sharing economy option again. J. Consum. Behav. 2015, 14, 193-207. [CrossRef]

37. Alemi, F.; Circella, G.; Mokhtarian, P.; Handy, S. What drives the use of ridehailing in California? Ordered probit models of the usage frequency of Uber and Lyft. Transport. Res. C Emer. 2019, 102, 233-248. [CrossRef]

38. Priporas, C.V.; Stylos, N.; Vedanthachari, L.N.; Santiwatana, P. Service quality, satisfaction, and customer loyalty in Airbnb accommodation in Thailand. Int. J. Tour. Res. 2017, 19, 693-704. [CrossRef]

39. Lalicic, L.; Weismayer, C. A model of tourists' loyalty: The case of Airbnb. J. Hosp. Tour. Technol. 2018, 9, 80-93. [CrossRef]

40. Pesonen, J.; Tussyadiah, I. Peer-To-Peer Accommodation: Drivers and User Profiles. In Collaborative Economy and Tourism: Perspectives, Politics, Policies and Prospects. Tourism on the Verge; Springer International Publishing: Berlin, Germany, 2016; pp. 285-303. [CrossRef]

41. Monaco, S. Tourism and the new generations: Emerging trends and social implications in Italy. J. Tour. Futures 2018, 4, 7-15. [CrossRef]

42. Rayle, L.; Shaheen, S.; Chan, N.; Dai, D.; Cervero, R. App-based, on-demand ride services: Comparing taxi and ridesourcing trips and user characteristics in San Francisco. Transp. Policy 2016, 45, 168-178. [CrossRef]

43. Alemi, F.; Circella, G.; Handy, S.; Mokhtarian, P. What influences travelers to use Uber? Exploring the factors affecting the adoption of on-demand ride services in California. Travel Behav. Soc. 2018, 13, 88-104. [CrossRef]

44. Alemi, F.; Circella, G.; Mokhtarian, P.; Handy, S. Exploring the latent constructs behind the use of ridehailing in California. J. Choice Model. 2018, 29, 47-62. [CrossRef]

45. Oppermann, M. First-time and repeat visitors to New Zealand. Tour. Manag. 1997, 18, 177-181. [CrossRef]

46. Fallon, P.; Schofield, P. First-timer versus repeat visitor satisfaction: The case of Orlando, Florida. Tour. Anal. 2003, 8, 205-210. [CrossRef]

47. Lau, A.L.; McKercher, B. Exploration versus acquisition: A comparison of first-time and repeat visitors. J. Travel Res. 2004, 42, 279-285. [CrossRef]

48. Wang, D. Tourist behaviour and repeat visitation to Hong Kong. Tour. Geogr. 2004, 6, 99-118. [CrossRef]

49. Kim, S.S.; Prideaux, B. Marketing implications arising from a comparative study of international pleasure tourist motivations and other travel-related characteristics of visitors to Korea. Tour. Manag. 2005, 26, 347-357. [CrossRef] 
50. Li, X.; Cheng, C.; Kim, H.; Petrick, J.F. A systematic comparison of first-time and repeat visitors via a two-phase online survey. Tour. Manag. 2008, 29, 278-293. [CrossRef]

51. Morais, D.B.; Lin, C. Why do first-time and repeat visitors patronize a destination? J. Trav. Tour. Mark. 2010, 27, 193-210. [CrossRef]

52. Vu, H.Q.; Li, G.; Law, R.; Ye, B.H. Exploring the travel behaviours of inbound tourists to Hong Kong using geotagged photos. Tour. Manag. 2015, 46, 222-232. [CrossRef]

53. Tasci, A.D. A quest for destination loyalty by profiling loyal travellers. J. Destin. Mark. Manag. 2016, 6, 207-220. [CrossRef]

54. Caber, M.; Albayrak, T. Does the importance of hotel attributes differ for senior tourists? A comparison of three markets. Int. J. Contemp. Hosp. Manag 2014, 26, 610-628. [CrossRef]

55. Talón-Ballestero, P.; González-Serrano, L.; Soguero-Ruiz, C.; Muñoz-Romero, S.; Rojo-Álvarez, J.L. Using big data from customer relationship management information systems to determine the client profile in the hotel sector. Tour. Manag. 2018, 68, 187-197. [CrossRef]

56. Pestana, M.H.; Parreira, A.; Moutinho, L. Motivations, emotions and satisfaction: The keys to a tourism destination choice. J. Destin. Mark. Manag. 2019. [CrossRef]

57. Homburg, C.; Giering, A. Personal characteristics as moderators of the relationship between customer satisfaction and loyalty? An empirical analysis. Psychol. Mark. 2000, 18, 43-66. [CrossRef]

58. Skogland, I.; Siguaw, J.A. Are Your Satisfied Customers Loyal? Cornell Hotel Restaur. Adm. Q. 2004, 45, 221-234. [CrossRef]

59. Sthapit, E.; Jiménez-Barreto, J. Exploring tourists' memorable hospitality experiences: An Airbnb perspective. Tour. Manag. Perspect. 2018, 28, 83-92. [CrossRef]

60. Bardhi, F.; Eckhardt, G. Access-based consumption: The case of car sharing. J. Consum. Res. 2012, 39, 1-18. [CrossRef]

61. Buda, G. Attitudes and motivations of consumers in sharing economy. In Management, Enterprise and Benchmarking in the 21st Century; EDIRC: Budapest, Hungary, 2017; pp. 22-30. Available online: https: //kgk.uni-obuda.hu/sites/default/files/02_Buda_Lehota.pdf (accessed on 15 November 2018).

62. Kim, B. Understanding Key Antecedents of Consumer Loyalty toward Sharing-Economy Platforms: The Case of Airbnb. Sustainability 2019, 11, 5195. [CrossRef]

63. Kim, T.T.; Kim, W.G.; Kim, H.B. The effects of perceived justice on recovery satisfaction, trust, word-of-mouth, and revisit intention in upscale hotels. Tour. Manag. 2009, 30, 51-62. [CrossRef]

64. Morosan, C.; Jeong, M. Users' perceptions of two types of hotel reservation web sites. Int. J. Hosp. Manag. 2008, 27, 284-292. [CrossRef]

65. Cusumano, M.A. How traditional firms must compete in the sharing economy. Commun. ACM 2015, 1, 32-34. [CrossRef]

66. Böcker, L.; Meelen, T. Sharing for people, planet or profit? Analyzing motivations for intended sharing economy participation. Environ. Innov. Soc. Transit. 2017, 23, 28-39. [CrossRef]

67. Schuckert, M.; Liu, X.; Law, R. Hospitality and tourism online reviews: Recent trends and future directions. J. Travel Tour. Mark. 2015, 32, 608-621. [CrossRef]

68. Mao, Z.; Lyu, J. Why travellers use Airbnb again? An integrative approach to understanding travellers' repurchase intention. Int. J. Contemp. Hosp. Manag. 2017, 29, 2464-2482. [CrossRef]

69. Liang, L.J.; Choi, H.C.; Joppe, M. Understanding repurchase intention of Airbnb consumers: Perceived authenticity, electronic word-of-mouth, and price sensitivity. J. Travel Tour. Mark. 2018, 35, 73-89. [CrossRef]

70. Pavlou, P.A.; Gefen, D. Building effective online marketplaces with institution-based trust. Inf. Syst. Res. 2004, 15, 37-59. [CrossRef]

71. Huang, D.; Liu, X.; Lai, D.; Zhiyong, L. Users and non-users of P2P accommodation: Differences in perceived risks and behavioral intentions. J. Hosp. Tour. Technol. 2019. [CrossRef]

72. Geddes, A.; Parker, C.; Scott, S. When the snowball fails to roll and the use of 'horizontal' networking in qualitative social research. Int. J. Soc. Res. Methodol. 2018, 21, 347-358. [CrossRef]

73. Huurne, M.; Ronteltap, A.; Corten, R.; Buskens, V. Antecedents of trust in the sharing economy: A systematic review. Int. J. Tour. Res. 2017, 16, 485-498. [CrossRef] 
74. Pollio, A. Forefronts of the sharing economy: Uber in Cape Town. Int. J. Tour. Res. 2019, 43, 760-775. [CrossRef]

75. Tussyadiah, I.P. Factors of satisfaction and intention to use peer-to-peer accommodation. Int. J. Hosp. Manag. 2016, 55, 70-80. [CrossRef]

(ब) (1)

(C) 2019 by the authors. Licensee MDPI, Basel, Switzerland. This article is an open access article distributed under the terms and conditions of the Creative Commons Attribution (CC BY) license (http://creativecommons.org/licenses/by/4.0/). 